\title{
Late Pleistocene and Holocene geomorphologic evolution of Laguna Las Vueltas area, Tierra del Fuego (Argentina)
}

\author{
Alejandro Montes ${ }^{1,2,3}$, Fernando Santiago ${ }^{1}$, Mónica Salemme ${ }^{1,2}$, Ramiro López ${ }^{1}$ \\ ${ }^{\prime}$ Centro Austral de Investigaciones Cientificas (CADIC-CONICET), Bernardo Houssay 200, Ushuaia 9410, Argentina. \\ alejandrogeomontes@gmail.com; ersant2@gmail.com; msalemme@cadic-conicet.gob.ar; ramirolopez@cadic-conicet.gob.ar \\ 2 Universidad Nacional de Tierra del Fuego, Antártida e Islas del Atlántico Sur, Fuegia Basket 251 (9410) Ushuaia, Tierra del \\ Fuego, Argentina. \\ 3 Universidad Nacional de la Patagonia San Juan Bosco, Ruta Provincial Nº , S/N, km 4, Comodoro Rivadavia 9000, Argentina.
}

\begin{abstract}
Laguna Las Vueltas (LLV) area retains the morphology of a late Pleistocene watershed that was flooded during a mid-Holocene marine transgression. Sediments associated with a paleosol dated at 22,582 cal yr BP reflect subaerial exposure of the area prior to the submergence during the marine transgression. This transgression produced an extensive tidal flat near the mouth of the former LLV watershed by 7,477 cal yr BP. Subsequent decoupling of the Las Vueltas valley from the sea occurred through the growth of a baymouth barrier and a beach-ridge plain to the east. This decoupling turned the lagoon into a pan environment in which subsequent lake-level fluctuations were controlled by climate. A lunette dune developed at the pans in the former lagoon, providing a narrow corridor where humans trapped, killed and processed guanacos as early as 3,402 cal yr BP. Changes in aeolian sedimentation hint at increased aridity during the past 500 years.
\end{abstract}

Keywords: Geomorphology, Incised valleys, Holocene marine transgression, Lunettes, Geoarchaeology, Pans.

RESUMEN. Evolución geomorfológica del área de Laguna Las Vueltas (Tierra del Fuego, Argentina) durante el Pleistoceno tardío y Holoceno. El área de Laguna Las Vueltas (LLV) conserva la morfología de una cuenca hídrica del Pleistoceno tardío que fue inundada durante la transgresión marina del Holoceno medio. Los sedimentos asociados con un paleosuelo datado en 22.582 cal yr AP reflejan la exposición subaérea del área con anterioridad a la transgresión marina. Esta transgresión provocó hacia $7.477 \mathrm{cal} \mathrm{yr} \mathrm{AP} \mathrm{una} \mathrm{extensa} \mathrm{planicie} \mathrm{de} \mathrm{marea} \mathrm{en} \mathrm{la} \mathrm{zona} \mathrm{baja} \mathrm{de} \mathrm{la} \mathrm{cuenca}$ de la LLV. La subsecuente desvinculación del valle de la LLV con el mar ocurrió a partir del desarrollo de una barrera litoral y una planicie de cordones de playa hacia el este. Este desacople convirtió a la albufera en una laguna somera (pan), donde las subsiguientes fluctuaciones de nivel del agua estuvieron controladas por el clima. Una duna de tipo "lunette" se desarrolló en el área de la antigua albufera, dando lugar a un corredor angosto donde los grupos humanos atraparon, mataron y procesaron guanacos desde al menos 3.402 años cal yr AP. Los cambios en la tasa de sedimentación eólica sugieren un incremento de la aridez en los últimos 500 años. 


\section{Introduction}

Shallow and salty lakes, termed "pans" (Shaw and Bryant, 2011; Villarreal and Coronato, 2017) are common coastal features on northeastern Tierra del Fuego. One of these pans, Laguna Las Vueltas (LLV, Fig. 1) is located within a steppe environment that extends from the Magellan Strait to the cape Viamonte area, south of the Río Grande, Argentina (Collado, 2007). Laguna Las Vueltas and other pans on Tierra del Fuego are the product of a marine transgression during the Holocene and subsequent isolation of former estuary mouths from the sea by the growth of barrier bars and dunes. Deflation of the bottom of the pans during dry periods produces clouds of dust that are carried eastward to the Atlantic Ocean (Goudie and Wells, 1995; Gaiero et al., 2007; Montes et al., 2017).

In this paper, we document the geomorphologic evolution of the LLV area from the late Pleistocene to the Present based on its geomorphology and sedimentary records. We discuss the origin of the dune in which the Las Vueltas 1 archaeological site (LV1) is situated, which was first occupied about 3,402 cal yr BP. Our specific objectives are to understand the morphology of these watersheds at northeastern Tierra del Fuego, reconstruct the Holocene landscapes in coastal areas and obtain information of climatic changes associated to the sedimentary and geomorphological processes of the area. These particular objectives lead to our main objective, which is to increase the understanding of the geomorphologic history of Tierra del Fuego during the period when hunters-gatherers first arrived to southernmost Argentina.

\section{Climate}

Tierra del Fuego lies within the circulation zone of the southern westerlies, which result from interaction of polar and subtropical air masses (Haltiner and Martin, 1957; Lambeck, 1980). The South Pacific anticyclone dries as it moves eastward over the Andes and generates strong and persistent föhen-type winds (Prohaska, 1976). This belt of low pressure, low precipitation, and turbulence lies between $40^{\circ}$ and $60{ }^{\circ} \mathrm{S}$, and moves northward in winter.

Climate at Río Grande, the closest meteorological station to LLV, is cold-temperate, with an average temperature of $10{ }^{\circ} \mathrm{C}$ in the warmest month
(February) and $-2{ }^{\circ} \mathrm{C}$ in the coldest month (August; Tukhanen, 1992). Westerly winds with an average speed of $29 \mathrm{~km} / \mathrm{h}$ occur $63 \%$ along a year (Servicio Meteorológico Nacional, 1986; Tukhanen, 1992). Mean annual precipitation is $333 \mathrm{~mm} /$ year (Iturraspe and Urciolo, 2002). The coast has a macro-tidal range of about $8.4 \mathrm{~m}$ (Servicio de Hidrografía Naval, 2008).

\section{Sea level change since the Last Glacial Maximum}

Sea level off the coast of Patagonia rose rapidly during the Last Glacial Maximum from a low-stand of about -105 m (Fig. 2a; Guilderson et al., 2000). Schellmann and Radtke (2010) describe a rapid early Holocene rise in sea level in central and southern Patagonia ( $44^{\circ}$ to $49^{\circ} \mathrm{S}$ ), which reached the current coastline about 8,600 cal yr BP. This transgression peaked between 7,400 and 6,600 cal yr BP, when the sea surface averaged 2-3 $\mathrm{m}$ above the present datum. On northeastern Tierra del Fuego, the maximum transgression was $+1.55-2.69 \mathrm{~m}$ in the Chico river area (Fig. $2 \mathrm{~b}$ ) and $+1.57 \mathrm{~m}$ in San Sebastián Bay (Bujalesky, 2007; Montes, 2015; Montes et al., 2018). Subsequently, sea level fell gradually until today (Violante et al., 2014a, b; Montes, 2015).

\section{Geology and soils}

The study area is underlain by Eocene-Miocene marine sedimentary rocks and Quaternary glacial, glacifluvial and littoral sediments (Meglioli, 1992; Malumian and Olivero, 2006). The LLV area was ice-free during the past four or five Pleistocene glaciations (Rabassa and Clapperton, 1990; Meglioli, 1992; Rabassa, 2008). Mid- and late Pleistocene coastal deposits have been recognized in northern Tierra del Fuego, associated to sand and gravel beaches (Bujalesky et al., 2001; Bujalesky, 2007). During Pleistocene transgressions, the area at the confluence of the Chico and Avilés rivers was a tidal inlet in which estuarine sediments accumulated up to $16 \mathrm{~km}$ landward of present-day lagunas Grande, de la Suerte and O'Connor (Bujalesky et al., 2001; Bujalesky, 2007). The Chico river mouth shifted southward during construction of a large Holocene beach ridge plain (Codignotto and Malumian, 1981; Bujalesky et al., 2001; Montes, 2015; Montes et al., 2018). 


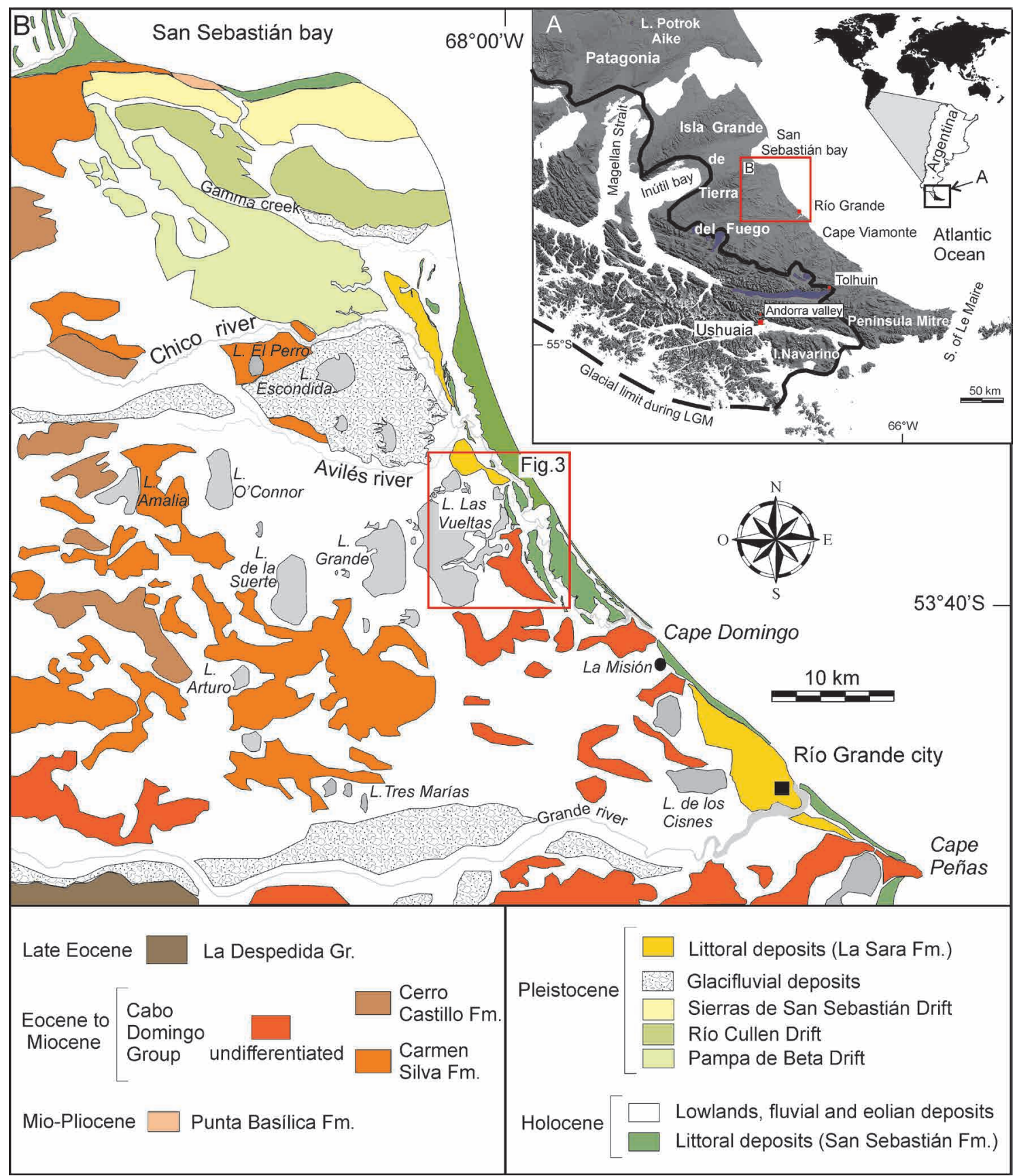

FIG. 1. A. Location map of Tierra del Fuego showing the glacial limit during the Last Glacial Maximum (LGM), modified from Rabassa (2008). B. Distribution of geologic units, modified from Codignotto and Malumián (1981), Meglioli (1992) and Malumián and Olivero (2006).

The soils in the study area are Mollisols and Inceptisols with relatively weak $\mathrm{A}$ and $\mathrm{C}$ horizons and loam to clay loam textures (Panigatti, 2010).
They support a herbaceous and grassland vegetation cover with wet grasslands under a xeric soil moisture regime (Collado, 2007). 
A

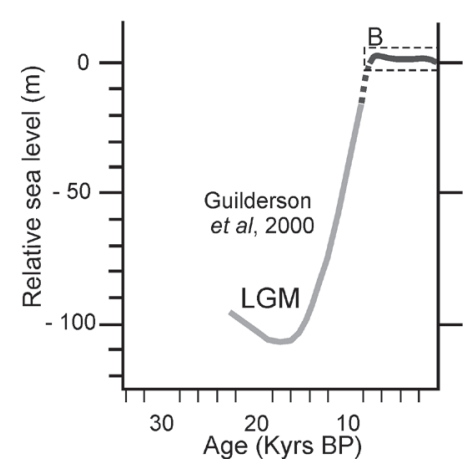

B

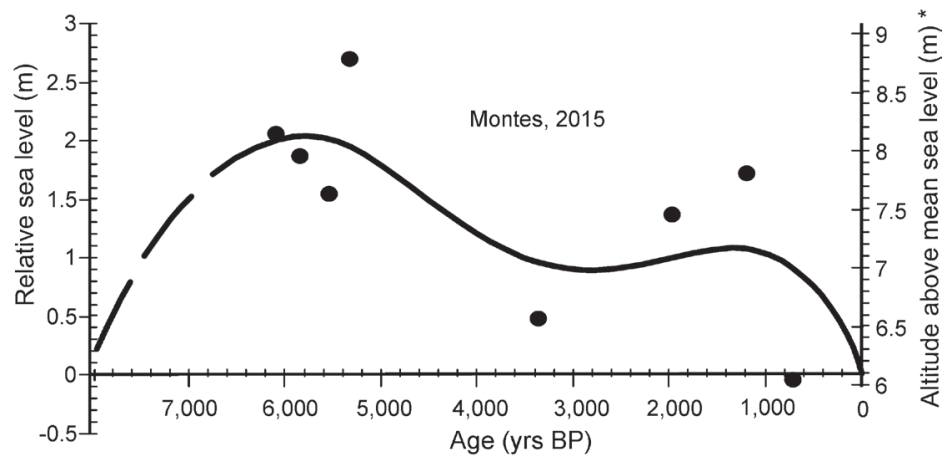

FIG. 2. Relative sea-level change curve derived from A. Argentine Shelf bathymetric data (Guilderson et al., 2000) and B. The Chico river area (Montes, 2015). Relative sea-level change in the Chico river area was determined by comparing elevations of Holocene beach ridge with the elevation of the current storm berm. Points are the time-altitude plot of Holocene dated samples. *WGS 84 datum and 12,039 m ellipsoid undulation (sensu Perdomo and Hormaechea, 1999).

\section{Human occupation}

Human groups have inhabited Tierra del Fuego since the early Holocene (Morello, 2000; Massone, 2003). Archaeological sites are associated with huntergatherer populations living mainly of guanaco hunting (Lama guanicoe). Pans would have concentrated different resources for the hunter-gatherer lifeway, not only water but fauna and raw material useful for the groups living in the area during the Holocene (Massone et al., 1993; Santiago, 2013; Oría et al., 2016).

The LV1 archaeological site at LLV (Fig. 3) is associated to aeolian deposits (Santiago and Salemme, 2009, 2010, 2016; Colasurdo et al., 2012; Santiago, 2013). It is a multicomponent site located between two pans with evidence for at least four occupation events. The first occupation $(3,402$ cal yr BP) is recorded by lithic and bone flakes and a few guanaco bones with human-inflected fractures. The second occupation (569 cal yr BP) is recorded by one hearth and numerous remains of at least six guanacos. A thin layer of $4 \mathrm{~cm}$ separates this occupation from the third one ( 545 to $525 \mathrm{cal} \mathrm{yr} \mathrm{BP}$ ), which is marked by a bonebed (sensu Behrensmeyer, 2007), which includes skeletal remains of guanaco and rodents, mostly tuco-tuco (Ctenomys magellanicus), also lithic tools, flakes and many microflakes (Negre et al., 2017; Santiago and Salemme, 2016; Santiago et al., 2016).

LV1 is an appropriate location space to trap, kill and process guanaco (Santiago, 2013). A lunette between the pans enabled hunter-gatherers to drive animals to a central point, where they could be more easily to kill them with bows and arrows. Guanacos were also processed and partially consumed at the place (Santiago and Salemme, 2016).

\section{Methods}

Satellite imagery from Google Earth (2017) and digital elevation models (ALOS PALSAR, 2011; spatial resolution $12.5 \mathrm{~m}$ ) were used to identify and map the main geomorphological units. The units were validated during the field survey. A topographic cross-section of the LV1 area was constructed with a differential GPS (ProMark 2), using the Stop and Go method with 30 seconds spent at each survey station. Data were processed in the field with Ashtech Solution 2.70 software. The vertical error in readings is estimated to be $2.2 \pm 0.7 \mathrm{~cm}$.

Stratigraphic data were obtained from dug pits and percussion cores. Grain size was estimated in the field using the size scale of Friedman and Sanders (1978). Sedimentary environments were inferred from sediment lithology, geometry, structure and fossils (Boyd et al., 1992; Galloway and Hobday, 1996). Samples of soil organic matter, bone and charcoal were collected from the LV1 archaeological site and dated at the University of Arizona AMS laboratory. Radiocarbon ages from previous studies (Salemme and Bujalesky, 2000; Bujalesky et al., 2001; Salemme et al., 2007; Coronato et al., 2011; Santiago, 2013) were also used for paleoenvironmental 
reconstructions and interpretations. Ages were calibrated using SHCal04.14c and IntCal09.14c (McCormac et al., 2004; Heaton et al., 2009). Ages in the text are calibrated radiocarbon ages, but noncalibrated ages are also included in table 1 .

\section{Results}

\subsection{Geomorphology of Laguna Las Vueltas area}

The LLV area is dominated by rounded hills composed of marine sedimentary rocks of the Cabo
Domingo Group (Eocene-Miocene; Malumián and Olivero, 2006). The Las Vueltas valley has been eroded into these sedimentary rocks, and pans have developed on the former valley floor near the coast (Fig. 1; Villarreal and Coronato, 2017).

LLV is a shallow temporary water body with a maximum surface area of $3 \mathrm{~km}^{2}$; it is recharged from precipitation, mainly during the winter season, and groundwater. It occupies the lower part of an endorheic basin that is fed by an intermittent stream from the southwest. The flat bottom of this and other pans in northern Tierra del Fuego and Patagonia is

TABLE 1. RADIOCARBON AGES FROM LLV, LV1 AND AEOLIAN DEPOSITS ASSOCIATED WITH LAGUNAS PERRO AND ARTURO.

\begin{tabular}{|c|c|c|c|c|c|c|c|c|}
\hline $\begin{array}{l}\text { Sample } \\
\text { code }\end{array}$ & Depth $^{1}$ & Location & Material & $\delta^{13} \mathrm{C}$ & ${ }^{14} \mathrm{C}^{2}$ & $\begin{array}{c}\text { Calibrated } \\
\text { age }\end{array}$ & $\begin{array}{c}\text { Calibration } \\
\text { data set }\end{array}$ & $\begin{array}{c}\text { Median } \\
\text { Probability }\end{array}$ \\
\hline \multicolumn{9}{|l|}{ SC1 } \\
\hline AA95376 & 63 & LV1.O2.M4 & Organic matter & -26.8 & post- 1950 & - & - & - \\
\hline AA95375 & 76 & LV1.01.M7 & Organic matter & -26.7 & post- 1950 & - & - & - \\
\hline
\end{tabular}

\section{SC2 (Main archaeological excavation) ${ }^{3}$}

\begin{tabular}{lrccccccc} 
AA82769 & 48 & LV1.F41.3 & Charcoal & -22 & $539 \pm 33$ & $500-550$ & shcal04.14c & 525 \\
AA85450 & 49 & LV1.F41 & Lama guanicoe & -21 & $563 \pm 45$ & $497-564$ & shcal04.14c & 536 \\
AA102165 & 52 & LV1 E33.4 & Charcoal & -23.1 & $585 \pm 38$ & $507-565$ & shcal04.14c & 545 \\
AA85451 & 70 & LV1.F41 & Lama guanicoe & -20.5 & $612 \pm 43$ & $515-648$ & shcal04.14c & 569 \\
AA95372 & 107 & LV1-E41-107 & Lama guanicoe & -20.6 & $3,018 \pm 51$ & $2,971-3,265$ & shcal04.14c & 3,144 \\
AA85449 & 130 & LV1.E41 NW & Lama guanicoe & -20.3 & $3,220 \pm 54$ & $3,246-3,514$ & shcal04.14c & 3,402 \\
\hline SC3 & & & & & & & \\
AA102162 & 215 & LV1.w3.N.2,15 & Organic matter & -25.1 & $6,613 \pm 51$ & $7,338-7,575$ & shcal04.14c & 7,477 \\
AA102161 & 385 & LV1.w3.N. 3,85 & Organic matter & -26.4 & $18,700 \pm 520$ & $21,331-23,827$ & intcal09.14c & 22,582
\end{tabular}

Perro 1 archaeological site ${ }^{4}$

\begin{tabular}{rrrrrrrrr} 
AA95373 & 76 & Pr1.S1.E1 & Lama guanicoe & -20.3 & $398 \pm 43$ & $322-496$ & shcal04.14c & 407 \\
AA95374 & 176 & Pr1.S1.E3 & Ctenomys sp. & -21.3 & $3,269 \pm 53$ & $3,344-3,586$ & shcal04.14c & 3,453 \\
\hline
\end{tabular}

\section{Lake Arturo sedimentary profile ${ }^{5}$}

\begin{tabular}{rrrrrrrrr} 
AA89591 & 424 & Palaeosol 7 & Lama guanicoe & -21 & $434 \pm 43$ & $324-515$ & shcal04.14c & 457 \\
AA89590 & 649 & Palaeosol 5 & Lama guanicoe & -20.7 & $4,871 \pm 59$ & $5,449-5,663$ & shcal04.14c & 5,545 \\
\hline
\end{tabular}

1 Depth is centimeters below the surface.

2 Calibrations performed with the Calib program (Stuiver and Reimer, 1993) using SHCa104.14c and IntCa109.14c (McCormac et al., 2004; Heaton et al., 2009).

3 Santiago and Salemme (2016).

4 Santiago (2013).

5 Coronato et al. (2011). 
controlled by the near-surface groundwater table, which serves as base-level control for aeolian deflation (Jacobson et al., 1994; Rosen, 1994). LLV is bordered to the northeast by a mid-Holocene littoral barrier with a crest $2.68 \mathrm{~m}$ above present sea level (Figs. 3-4a; Montes, 2015). Neither the valley floor nor the headwater show evidence of active water erosion. The valley widens and constricts irregularly, and forms a poorly integrated and interrupted drainage network composed of small pans and wetlands (Fig. 3).

Waves formed by the dominant westerlies favor the development of sandy-gravel beaches and erosion scarps within pans. Beach scarps are present on the east side of the small pan at LV1 and show that water levels were higher in the past than today (Fig. 4c).

Aeolian deposits are common as lunettes, perched dunes and thin mantles on the east side of the pans (Coronato et al., 2011). The LV1 archaeological site is located within a lunette that is $570 \mathrm{~m}$ long and forms a corridor up to $150 \mathrm{~m}$ wide bordered by two pans: a small one on the east and a large one (LLV) on the west (Fig. 3b).

\subsection{Stratigraphy}

The stratigraphy of five pits and core-samples (SC1 to SC5) from the study area was recorded. SC1, $\mathrm{SC} 2, \mathrm{SC} 3$, and SC4 lie along an east-west transect

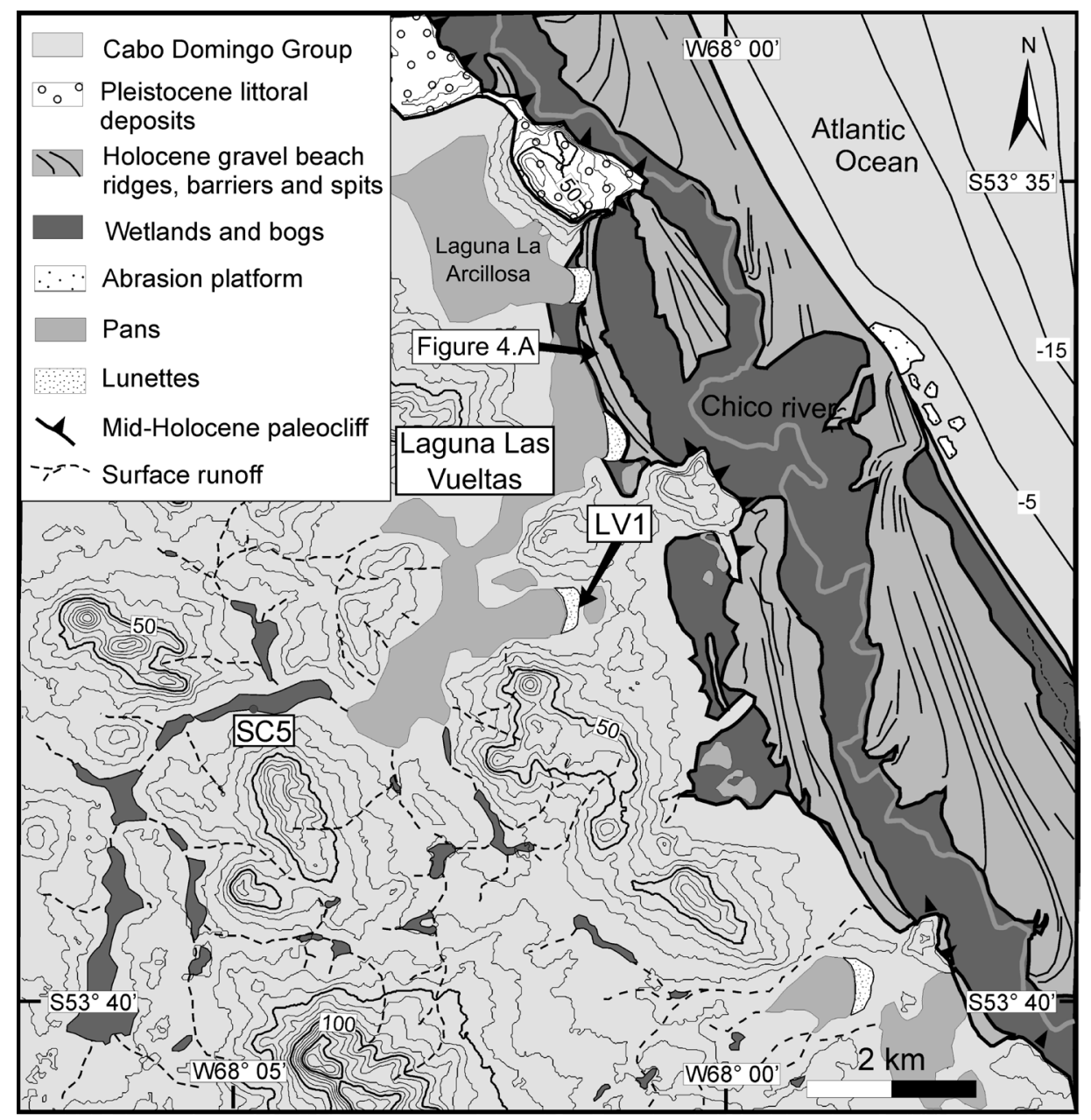

FIG. 3. Geomorphology of the study area; LV1: Las Vueltas 1 archaeological site; SC5: Stratigraphic column. LLV and other pans are bordered on the east by a mid-Holocene littoral barrier (Bujalesky et al., 2001). 


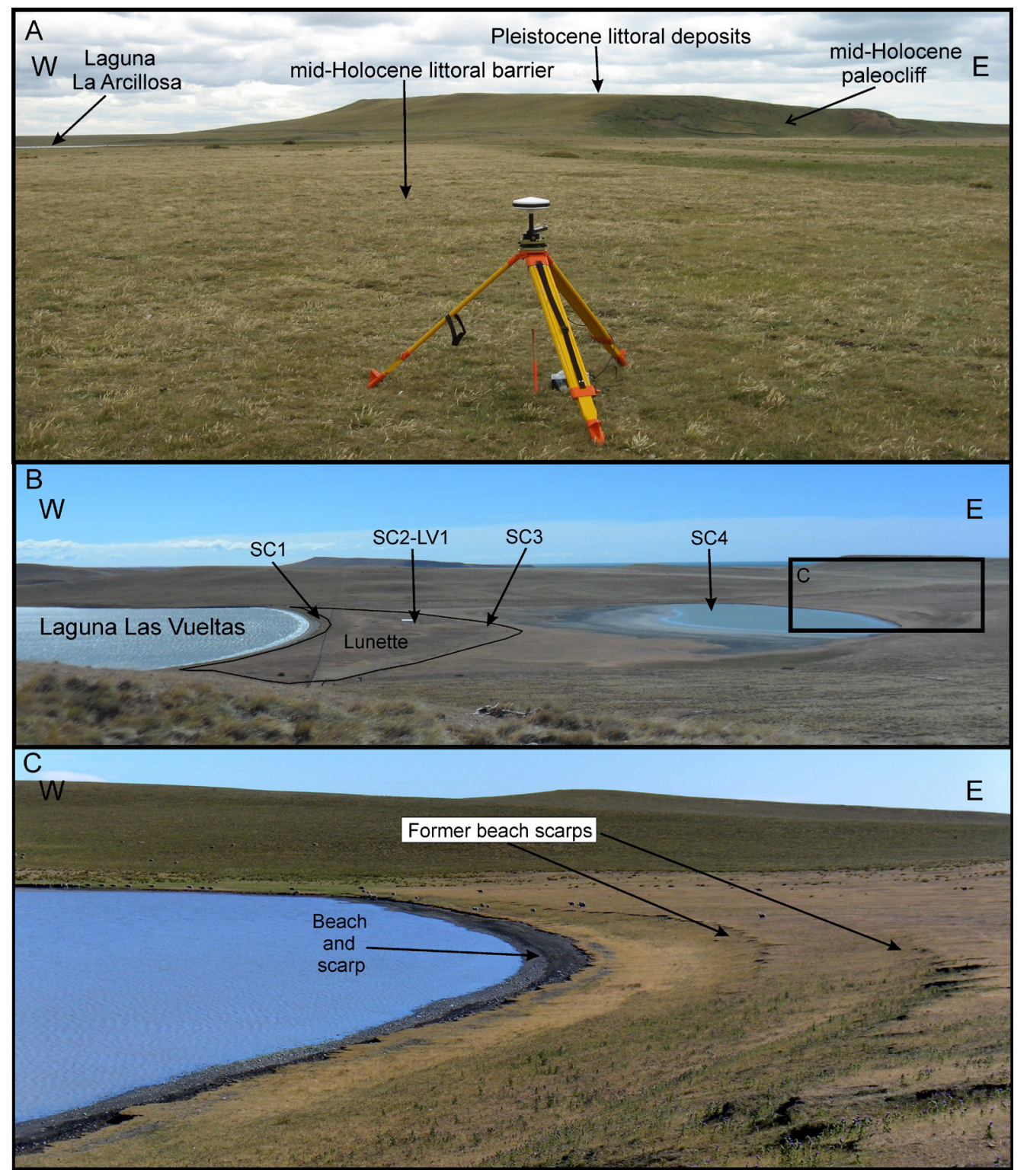

FIG. 4. A. Mid-Holocene littoral barrier located east of LLV and Laguna La Arcillosa (Fig. 3). B. Panoramic view of the LV1 archaeological site and its surroundings. C. View of the small pan located east of LV1, showing current and former beach scarps. Note the contrast in vegetation between the thin aeolian mantle and the surrounding hills. SC: Stratigraphic columns location.

across the lunette and include the archaeological site LV1 (Figs. 3, 4b-5a). SC5 is a core taken at the west side of the LLV area in a frequently submerged wetland (Figs. 3-5b).

SC1 (Fig. 4b) is a pit on the upper beach scarp of LLV (5337'49.9” S, 6801'41.2” W; Fig. 5a). It shows alternating layers of well sorted, medium sand, sandy gravel with abundant plant matter; the beds are less than $13 \mathrm{~cm}$ thick. Post-1950 radiocarbon ages were obtained on plant remains of the deepest organic layers (O1 and $\mathrm{O} 2$; Table 1).

$\mathrm{SC} 2$ (Fig. 4b) is a pit near the crest of the lunette located east of SC1 (53 $\left.37^{\circ} 42.7^{\prime \prime} \mathrm{S}, 68^{\circ} 01^{\prime} 39.0^{\prime \prime} \mathrm{W}\right)$. Dark brown, sandy clayey is present at the base of the pit $1.97 \mathrm{~m}$ below the surface. Faunal remains (Lama guanicoe and Ctenomys sp.) with anthropic evidence 


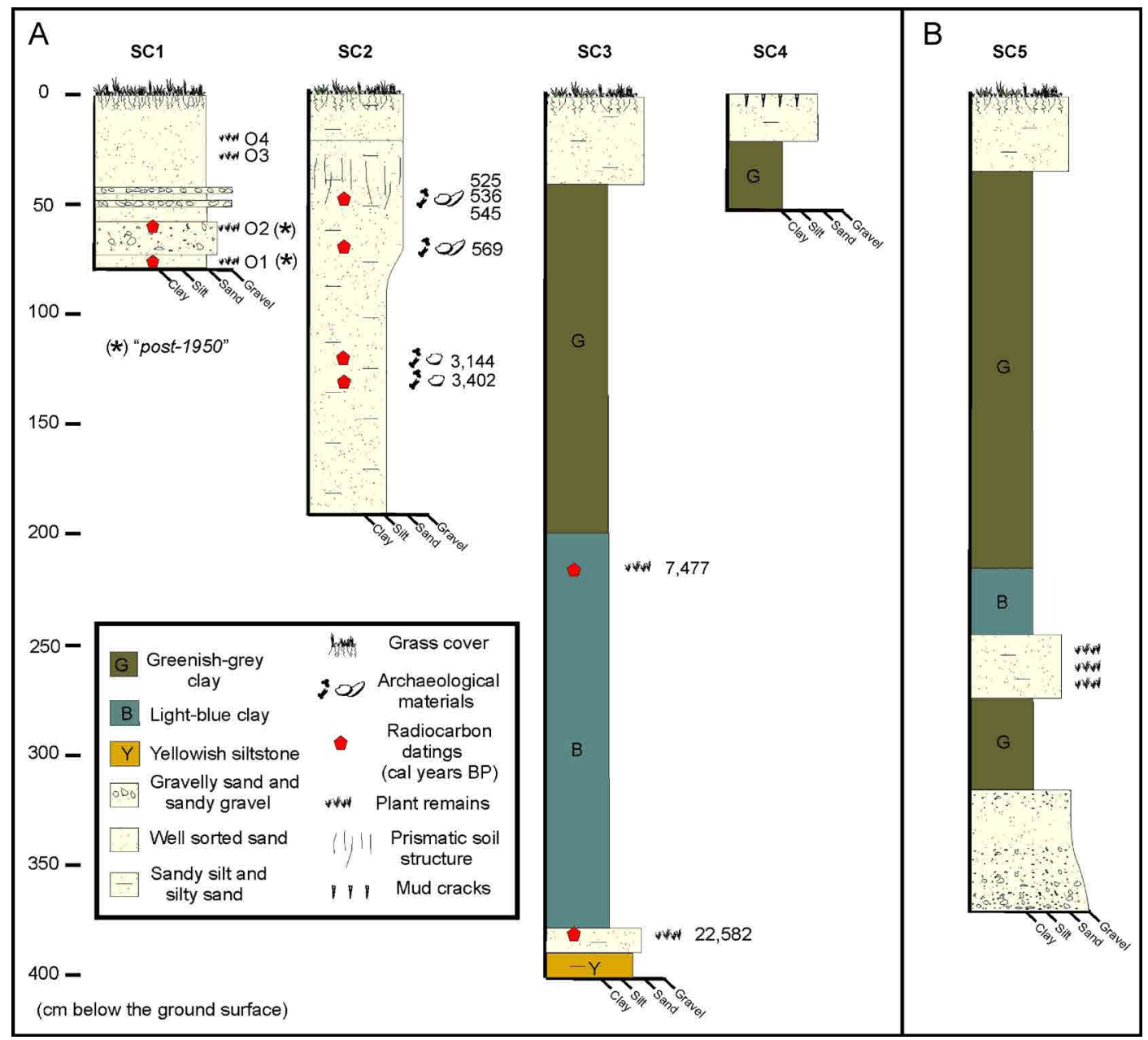

FIG. 5. Stratigraphic columns (SC) of (A) dug pits (SC1-SC4) and (B) a core (SC5) (see figures 3 and 4b for locations). Layers rich in plant remains at $\mathrm{SC} 1$ are numbered $\mathrm{O} 1$ to $\mathrm{O} 4$ for easy reference.

were found 1.2-1.3 $\mathrm{m}$ below the surface, and dated to 3,402 and 3,144 cal yr BP (Fig. 5a). Above $80 \mathrm{~cm}$ depth, the sediments coarsen to dark brown silty sand with abundant archaeological and bone remains (mainly Lama guanicoe, but Mytilus sp. shells, charcoal associated with a hearth, and lithic artifacts are also present). Radiocarbon ages from this level are 569 and 525 cal yr BP (Figs. 5b-6a). A poorly developed soil with prismatic structure is present near the ground surface. It is covered by aeolian silty fine sand supporting roots and grasses.

$\mathrm{SC} 3$ (Fig. 4b) is a $4 \mathrm{~m}$ long core and located east of LV1 (S5337'42.7' W68 01'36.5") (Fig. 5a). Yellowishbrown, clayey siltstone of the Cabo Domingo Group is present at the base of the core (Fig. 6b). At $3.88 \mathrm{~m}$, the siltstone is overlain by a dark, organic-rick silty sand with traces of fine roots, which yielded a radiocarbon age of 22,582 cal yr BP (Table 1). We interpret this unit to be a paleosol. Above $3.79 \mathrm{~m}$ are $1.8 \mathrm{~m}$ of light blue clay with plant fragments (possibly Salicornia sp.), which yielded a radiocarbon age of 7,477 cal yr BP (Table 1). The clay is overlain by $1.45 \mathrm{~m}$ of greenishgray clay. The uppermost $45 \mathrm{~cm}$ of the core is sand with a capping weakly developed soil covered by grass.

The pit at $\mathrm{SC} 4$ is $0.53 \mathrm{~m}$ long and located east of SC3 (S5337'42.8' W68 01'26.9'”) (Fig. 4b). Thirty-one centimetres of greenish-grey clay are overlain by $22 \mathrm{~cm}$ of clayey fine sand (Fig. $5 \mathrm{a}$ ). The surface at this location exhibited mud cracks due to drying of the pan surface at the time the pit was dug. 


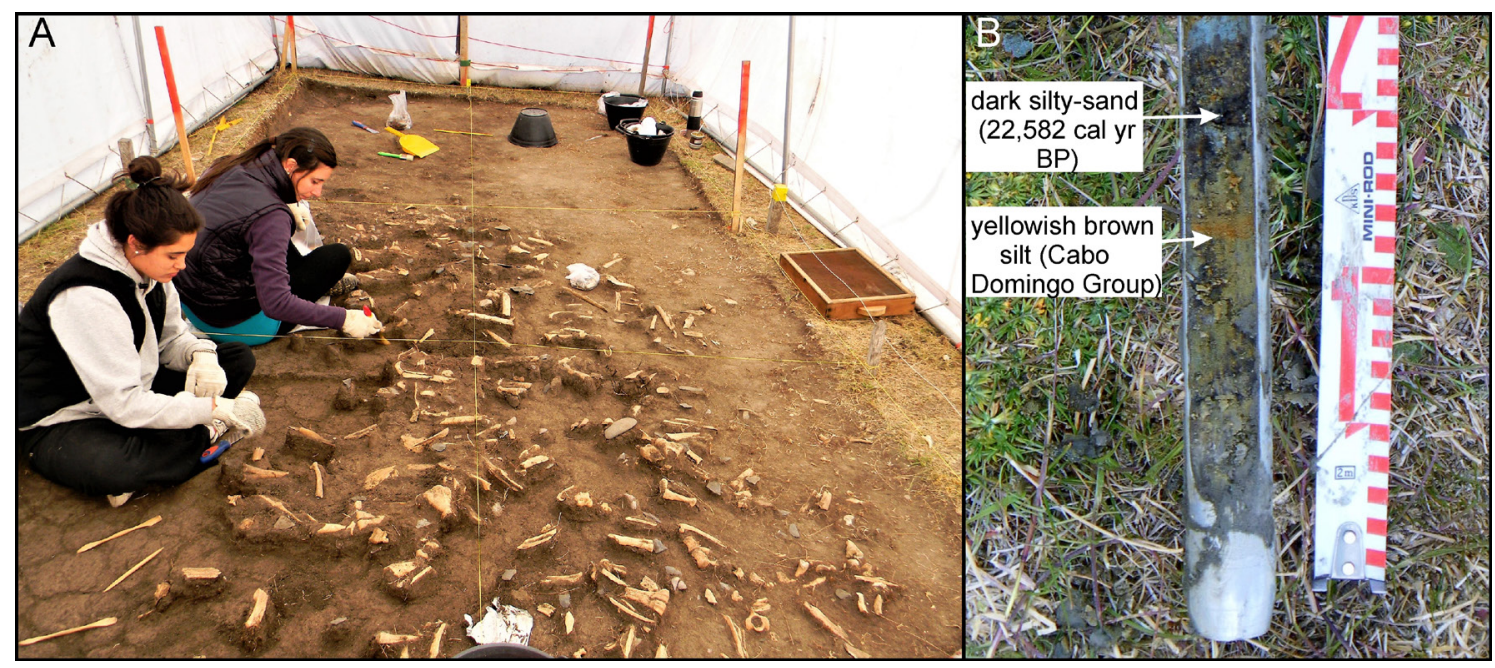

FIG. 6. A. The bone bed at the LV1 archaeological site. B. Lower part of the core at SC3 showing a dark paleosol developed on sedimentary rocks of Cabo Domingo Group.

SC5 is a $3.69 \mathrm{~m}$ long core located west of LLV (S5338'17.1", W6804'55.1”) (Fig. 5b). Matrixsupported gravel is present at the base of the core. The gravel fines upward to coarse sand over a distance of $52 \mathrm{~cm}$. Scattered fine gravel is present at the top of this unit. Above, it is $42 \mathrm{~cm}$ of gray-green clay. Dark, organic-rich sandy silt occurs at depths of $2.45-2.75 \mathrm{~m}$ and is covered by $30 \mathrm{~cm}$ of light-blue clay. The clay, in turn, is overlain by $1.83 \mathrm{~m}$ of gray-green clay. The uppermost $32 \mathrm{~cm}$ of the core is silty sand.

\section{Discussion}

The coastal area between San Sebastián Bay and Río Grande was not glaciated during most of the Pleistocene (Fig. 1a), but meltwater streams from glaciers to the west reached the coast, and the area was affected by marked sea-level changes accompanying the build-up and decay of the Patagonian ice sheet (Bujalesky et al., 2001; Bujalesky, 2007). The absence of Pleistocene marine and littoral deposits of La Sara Formation in the LLV basin suggests that the basin is younger than Marine Isotopic Stage (MIS) 5e, because the sandygravel coastal terrace associated to this interglacial period on Tierra del Fuego are typically higher in elevation than the floor of the basin (16-17 m above mean sea level; Codignotto and Malumián, 1981; Bujalesky, 2007). During the Last Glacial
Maximum, sea level fell to about $-105 \mathrm{~m}$ below its present position and the coastline was far to the east of its present location (Rabassa, 2008; Ponce et al., 2011; Violante et al., 2014a, b). Cutler et al. (2003) identified four periods of rapid sea-level fall between MIS 5e and MIS 2 with rates between 2.9 and $10.6 \mathrm{~m} / \mathrm{ka}$. Rapid lowering of sea level would lower base level and might cause an expansion of the drainage network and valley incision in the study area, as in other coastal areas of the world (Greene et al., 2007; Sloss et al., 2007). The friable sediments of the Cabo Domingo Group are susceptible to weathering and erosion and thus may have contributed to the development of a drainage network whose morphology is partially preserved today (Fig. 7a). The finingupward gravel/sand unit at the bottom of the core at SC5 is interpreted to be fluvial sediment deposited in the LLV paleovalley before MIS 2. Sediments in the core at SC3 dated at 22,582 cal yr BP reflect subaerial conditions after the end of the incision of the paleovalley.

Sea level rose at a rate of $11-12 \mathrm{~mm} \mathrm{a}^{-1}$ early after the Last Glacial Maximum, and even faster later (Guilderson et al., 2000; Cavallotto et al., 2004; Violante and Parker, 2004; Schnack et al., 2005). With the rise in base level and increased aridity, the studied drainage network may have disintegrated. Winds eroded the bottoms and sidewalls of the valleys. These processes generated the present landscape, with wetlands and small deflation basins 


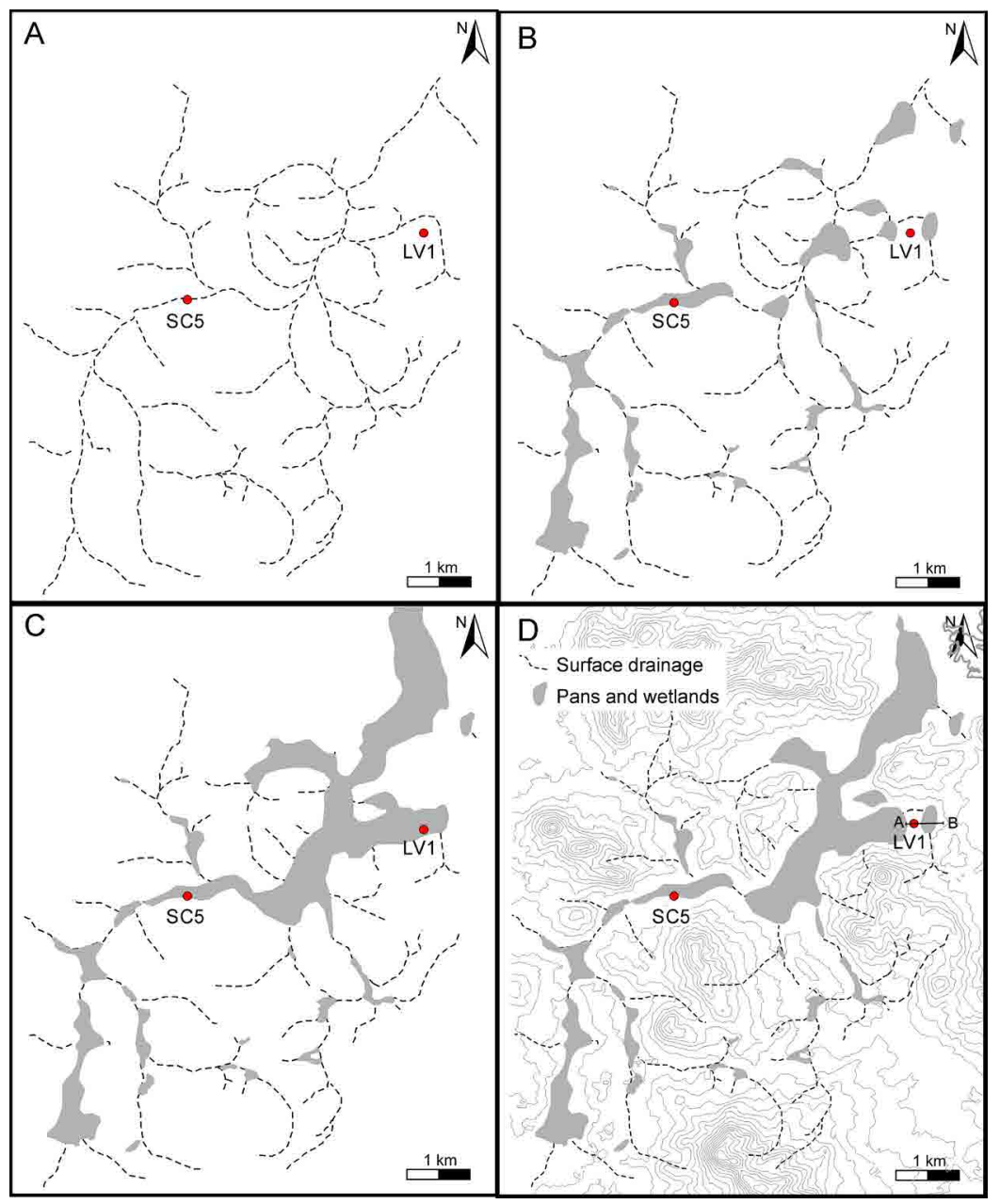

FIG. 7. Evolution of the drainage network in the LLV area: A. Late Pleistocene, B. Early Holocene, C. Mid-Holocene, D. Present (A-B: topographic cross-section; see figure 8). LV1: Las Vueltas 1 archaeological site; SC5: stratigraphic column 5.

blocking the drainage system (Fig. 7b). The regional decrease in precipitation during the Late Glacial and alternating wetter and drier periods during the Holocene (Coronato et al., 2011; Massaferro et al., 2012; Schäbitz et al., 2013; Oehlerich et al., 2015; Borromei et al., 2018) may have promoted these environmental changes.

During the mid-Holocene, the lower area of the Las Vueltas valley was flooded and became a lagoon in which the clay dated at 7,477 cal yr BP was deposited. These sediments are associated with the maximum Holocene marine transgression (Fig. 7c). The lagoon was situated behind a gravel bay-mouth barrier that developed between the ancient headlands of the Cabo Domingo sedimentary rocks (Fig. 3).
Similar sedimentary sequences to those recognized in LLV area have been described by Auer (1974), Markgraf (1980) and Mörner (1991) at the La Misión site, a few kilometers south of the study area. Those authors identified a lake deposit, dated about $9,000{ }^{14} \mathrm{C}$ yr BP, and younger tidal-flat sediments capping peat deposits. In this sense, they recognized the postglacial transgression levels between continental deposits. Similar ideas on the evolution of coastal incised valleys and blocking Holocene baymouth barriers have been presented by Roy (1984) and Sloss et al. (2007) at coastlines in southeastern Australia that are tectonically stable and were subject to similar sea-level changes as those on eastern Tierra del Fuego (Baker and Haworth, 2000; Belperio et al., 2002). 
The growth of the baymouth barrier and subsequent development of the beach-ridge plain to the east closed the marine entrance to LLV (Bujalesky, 2007; Montes, 2015), decoupling the Las Vueltas valley from any tidal influence. This decoupling turned the lagoon into a pan environment (Iturraspe and Urciuolo, 2002; Villarreal and Coronato, 2017; Borromei et al., 2018). The fall in relative sea level since the mid-Holocene maximum $\left(0.352 \mathrm{~mm} \mathrm{yr}^{-1}\right.$; Montes, 2015) contributed to a ca. 2 m reduction in water levels and a coincident increase in deflation activity (Coronato et al., 2011; Massaferro et al., 2012). Low water levels disconnected several small pans and wetlands and led to the development of the lunette bedforms that were occupied by humans at 3,402 cal yr BP (Fig. 8).

Lancaster (1978) proposed that pan-margin lunette dunes are derived from sediment deflated from pan floors at times of dry climate. Small fluctuations of water level in LLV leave the panfloor sediments partially or totally unprotected and available for entrainment and wind transport. The lunette east of LLV is the product of strong westerlies that dominate wind circulation in Tierra del Fuego (Mazzoni and Vazquez, 2009; Villarreal and Coronato, 2017; Montes et al., 2016, 2017). The aeolian sediments forming the lunette comprise fine sand, silt and clay. Muddy particles are lifted from the lake bottom by wind and carried to the lunette where they are deposited. After deposition, these particles lose cohesion when exposed to rainwater (Tricart, 1969; Arche and Vilas, 1986-1987). Silt and clay are mobilized and transported to depth, where they become concentrated (SC2). This process destroys any sedimentary structures that may have been present, giving the sediment and generates a post-depositional reverse gradation (Arche and Vilas, 1986-1987; Oría et al., 2010).

Dune development in Fuegian steppe pans buried archaeological materials, favoring their preservation (Favier Dubois and Borrero, 2005; Oría et al., 2010; Coronato et al., 2011; Santiago, 2013; Montes et al., 2016). The studied lunette provided a corridor up to $150 \mathrm{~m}$ wide and $570 \mathrm{~m}$ long that was an appropriate place to trap, kill and process guanacos. It thus supported the hunting activities of human groups inhabiting the northern portion of Tierra del Fuego (Santiago and Salemme, 2016). Zooarchaeological analysis and identification of a hearth and bonebed suggest that the second and third human occupation layers of the LV1 site were rapidly buried, likely during periods of lower lake levels.

Radiocarbon ages and stratigraphical provenance of archaeological remains at LV1 were used to calculate aeolian sedimentation rates (Table 2). Data from other sites on eastern Tierra del Fuego (Perro 1 and Arturo 1; Fig. 1, Table 1) were included to estimate aeolian deposition more regionally. Laguna Perro is located $22 \mathrm{~km}$ northwest of LV1. The archaeological site there is buried by aeolian sediments (Santiago, 2013). Two archaeological sites have been studied at Laguna Arturo, located approximately $20 \mathrm{~km}$ southwest of LLV (Oría and Salemme, 2016). Aeolian sedimentation rates there

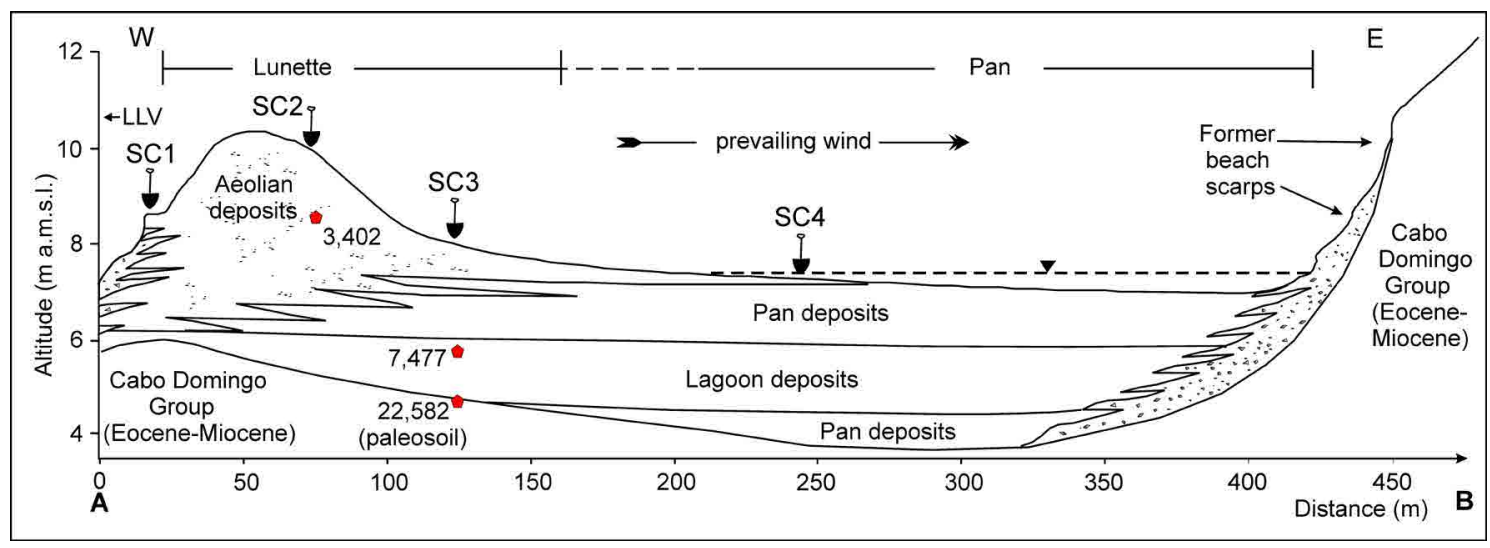

FIG. 8. Topographic cross-section showing depositional environments, calibrated radiocarbon ages (red polygons, cal yr BP), and the Eocene-Miocene substrate. See figure 7 for location of cross-section. SC stratigraphic columns (see figure $4 \mathrm{~b}$ for location); dashed line present water level. 
TABLE 2. ESTIMATED AEOLIAN SEDIMENTATION RATES AT THREE DIFFERENT SITES ON THE FUEGIAN STEPPE.

\begin{tabular}{|c|c|c|c|c|}
\hline Site & Age ${ }^{14} \mathrm{C} B P$ & Sample code & Depth (cm) & Sedimentation rates $(\mathrm{mm} / \mathbf{y r})$ \\
\hline \multirow{2}{*}{ Las Vueltas 1} & 569 & AA85451 & 70 & 1.230 \\
\hline & 3,402 & AA85449 & 130 & 0.212 \\
\hline \multirow{2}{*}{ Perro 1} & 407 & AA95373 & 76 & 1.867 \\
\hline & 3,453 & AA95374 & 176 & 0.328 \\
\hline \multirow{2}{*}{ Arturo 1} & 457 & AA89591 & 424 & 9.769 \\
\hline & 5,545 & AA89590 & 649 & 0.442 \\
\hline
\end{tabular}

exceed those at the LV1 and Perro sites over similar periods. Sedimentation rates at all three sites were higher over the past 500 years than before. This increase may be due to drier climatic conditions during the Little Ice Age, which caused a lowering and drying of lakes in the Fuegian steppe. This hypothesis is consistent with the observations of Favier Dubois (2003), who concluded that Mollisols formed in northern Tierra del Fuego and southern Patagonia are a result of a regional moisture increase during the Medieval Warm Period (MWP), followed by drier conditions and burial of soils by aeolian deposits.

The pit at SC1 (Figs. 5a-6a) displays an alternation of sand beds, organic-rich horizons, and sandy gravel beds. Well sorted sand beds are interpreted to be aeolian sediment transported from the nearby LLV beach to the west. The gravelly sand and sandy gravel beds are similar to modern pan beach deposits a few metres away, they have the same grain size distributions, similar clast shape (generally discoidal), and slope $(5-7 \%)$. These beds thus record periods of high lake level relatively wetter climate. The organic-rich horizons record times when vegetation colonized aeolian or beach sediments (Jenkinson, 1988); the plant remains are the same grasses that presently grow around the lake. They would be associated with periods of intermediate lake levels, during which the areas east of LLV also support grasses.

The LLV water-level fluctuations have a maximum amplitude of less than $2 \mathrm{~m}$, measured from the bottom of the lake to the top of the upper beach scarp. These fluctuations seem to be recent because the organic horizons at SC1 (Fig. 5a) yielded "post-1950" radiocarbon ages. These ages indicate that three times of higher lake levels occurred during the recent decades and might be related to the fluctuations in
Laguna de los Cisnes measured by Iturraspe and Urciuolo (2002) over the period 1974-2001.

\section{Conclusions}

This study is one in a series of paleoenvironment reconstructions of coastal landforms and sedimentary sequences on Tierra del Fuego made over the past four decades (Auer, 1974; Markgraf, 1980; Mörner, 1991; Bujalesky et al., 2001; Montes et al., 2016; Montes and Martinioni, 2017; Montes et al., 2018). It contributes to understanding landscape evolution in areas affected by sea-level change. The landscape and sediment interpretations are consistent with: 1) a rise in sea level after the LGM as described by Guilderson et al. (2000), Ponce et al. (2011) and Violante et al. (2014 a, b); 2) the high-stand in sea level during the middle Holocene (around +2 ); and 3) the following fall in sea level described by Bujalesky et al. (2001) and Montes (2015) in the Chico river area. The evolution of the Las Vueltas valley has similarities with that of the La Misión valley where lake sediments were transgressed during the post-LGM rise in sea level, and a tidal flat was replaced by a lake during the mid-Holocene (Auer, 1974; Markgraf, 1980; Mörner, 1991).

Key conclusions from our study are the following: 1. The irregular morphology of the Las Vueltas area is related to an ancient drainage network dated about Late Pleistocene. Valley incision accompanied the falls in sea level after MIS 5e. Deflation basins formed under an arid climate, creating the irregular morphology of the valleys. A paleosol dated at 22,582 cal yr $\mathrm{BP}$ records subaerial exposure of the area that was subsequently submerged. The darker colour and abundant organic matter observed in SC3 
and SC5 stratigraphic sections suggest humid conditions, at least locally.

2. A marine transgression generated an extensive tidal flat during the mid-Holocene. This tidal flat covered the LLV area and its surrounding pans. Decoupling of the Las Vueltas valley from the sea occurred when a baymouth barrier and beachridge plain blocked the mouth of the valley. The lagoon was transformed into a pan environment with water-level changes controlled by climate and the fall in sea level from the mid-Holocene high stand.

3. Lunette development between pans at LLV area generated a narrow corridor that favored trapping, killing and processing of guanacos as early as 3402 cal yr BP. Aeolian sedimentation during dry periods buried the archaeological remains. Estimates of aeolian sedimentation rates from LLV and two other sites on the Fuegian steppe suggest that aridity has increased over the past 500 years.

\section{Acknowledgements}

We thank J. Rabassa, J. Federico Ponce (CADICCONICET) and J. Clague (Simon Fraser University) for reviews that improved the preliminary manuscript. Cristina San Martín (CADIC-CONICET) helped us with GIS. We thank the creation of Ministerio de Ciencia, Tecnología e Innovación Productiva in December 2007, which allows the growth of Scientific System of Argentina. Funding for the research was provided by CONICET (Grants PIP 0302 to FS and PIP 0422-10 to MS) and the Agencia Nacional de Promoción de la Ciencia y la Tecnología (Grant PICT 2012-1944 to MS). We also thank F. Isla, E. Fucks, G. Bujalesky and W. Vivallo for their comments and suggestions that improved the manuscript.

\section{References}

ALOS PALSAR. 2011. ALPSRP271186080 JAXA/ METI.

Accessed through https://vertex.daac.asf.alaska.edu/ (Last visit 26/12/2017).

Arche, A.; Vilas, F. 1986-1987. Depósitos eólicos de grano fino en la Bahía de San Sebastián, Tierra del Fuego, Argentina. Acta Geológica Hispánica 21-22: 261-266.

Auer, V. 1974. The isorhythmicity subsequent to the Fuego-Patagonian and Fennoscandian ocean level transgressions and regressions of the latest glaciations. Annales Academiae Scientiarum Fennicae, Series A3, 115: 1-88.
Baker, R.; Haworth, R. 2000. Smooth or oscillating late Holocene sea-level curve? Evidence from cross-regional statistical regressions of fixed biological indicators. Marine Geology 163: 353-365.

Belperio, A.P.; Harvey, N.; Bourman, R. 2002. Spatial and temporal variability in the Holocene sea-level record of the South Australian coastline. In Sedimentary Geology (Fletcher, C.H.; Murray-Wallace, C.V.; editors). Elsevier, Coastal environmental change during sea-level highstands 150 (1-2): 153-169.

Behrensmeyer, A.K. 2007. Bonebeds through time. In Bonebeds: Genesis, Analysis, and Paleobiological Significance (Rogers, R.R.; Eberth, D.A.; Fiorillo, A.R.; editors). University of Chicago Press: 65-102. Chicago.

Borromei,A.M.; Candel, M.S.; Musotto, L.L.; Cusminsky, G.; Martínez, M.A.; Coviaga, C.A.; Ponce, J.F.; Coronato, A. 2018. Late Holocene wet/dry intervals from Fuegian steppe at Laguna Carmen, southern Argentina, based on a multiproxy record. Palaeogeography, Palaeoclimatology, Palaeoecology 499: 56-71. doi: 10.1016/j.palaeo.2018.03.008.

Boyd, R.; Dalrymple, R.W.; Zaitlin, B.A. 1992. Classification of coastal sedimentary environments. Sedimentary Geology 80: 139-150.

Bujalesky, G.G. 2007. Coastal geomorphology and evolution of Tierra del Fuego (Southern Argentina). Geologica Acta 5 (4): 337-362.

Bujalesky, G.G.; Coronato, A.J.; Isla, F.I. 2001. Ambientes glacifluviales y litorales cuaternarios de la región del río Chico, Tierra del Fuego, Argentina. Revista de la Asociación Geológica Argentina 56 (1): 73-90.

Codignotto, J.O.; Malumián, N. 1981. Geología de la región al Norte del paralelo $54^{\circ} \mathrm{S}$. de la Isla Grande de Tierra del Fuego. Revista de la Asociación Geológica Argentina 36 (1): 44-88.

Colasurdo, M.B.; Santiago, F.; Salemme, M. 2012. Guanacos: sexo y edad. El caso del sitio Las Vueltas 1 (Tierra del Fuego, Argentina). Comechingonia 16 (2): 195-209. Córdoba.

Collado, L. 2007. La vegetación de Tierra del Fuego: de la estepa a la selva. In Patagonia Total, Antártida e Islas Malvinas (Godoy Martínez, C.; editor). Barcel Baires Ediciones: 755-772. Buenos Aires.

Coronato, A.J.; Fanning, P.; Salemme, M.; Oría, J.; Pickard, J.; Ponce, J.F. 2011. Aeolian sequence and the archaeological record in the fuegian steppe, Argentina. Quaternary International 245: 122-135.

Cavallotto, J.L.; Violante, R.A.; Parker, G. 2004. Sea level fluctuations during the last $8600 \mathrm{yrs}$ in the Río de la Plata (Argentina). Quaternary International 114: 155-165. 
Cutler, K.B.; Edwards, R.L.; Taylor, F.W.; Cheng, H.; Adkins, J.; Gallup, C.D.; Cutler, P.M.; Burr, G.S.; Bloom, A.L. 2003. Rapid sea-level and deep-ocean temperature change since the last interglacial period. Earth and Planetary Science Letters 206: 253-271.

Favier Dubois, C. 2003. Late Holocene climatic fluctuations and soil genesis in southern Patagonia: effects on the archaeological record. Journal of Archaeological Science 30: 1657-1664.

Favier Dubois, C.; Borrero, L.A. 2005. Playas de acreción: Cronología y procesos de formación del registro arqueológico en la costa central de la bahía San Sebastián, Tierra del Fuego (Argentina). Magallania 33: 83-98.

Friedman, G.M.; Sanders, F.E. 1978. Principles of Sedimentology. John Wiley and Sons: p. 792.

Gaiero, D.M.; Brunet, F.; Probst, J.; Depetris, P.J. 2007. A uniform isotopic and chemical signature of dust exported from Patagonia: rock sources and occurrence in southern environments. Chemical Geology 238 (1-2): 107-120.

Galloway, W.E.; Hobday, D.K. 1996. Terrigenous clastic depositional systems: applications to fossil fuel and groundwater resources. Springer-Verlag: p. 489. NewYork

Google Earth. 2017. http://www.google.com /maps/@$53.60817,-67.97744,16677 \mathrm{~m} /$ data $=! 3 \mathrm{~m} 1$ ! $1 \mathrm{e} 3$. (Last visit 27/12/2017).

Goudie, A.S.; Wells, G.L. 1995. The nature, distribution and formation of pans in arid zones. Earth Science Reviews 38: 1-69.

Greene, D.L.; Rodríguez, A.B.; Anderson, J.B. 2007. Seaward-branching coastal-plain and piedmont incised-valley systems through multiple sea-level cycles: Late Quaternary examples from mobile bay and Mississippi sound, U.S.A. Journal of Sedimentary Research 77: 139-158.

Guilderson, T. P.; Burkle, L.; Hemming, S.; Peltier, W.R. 2000. Late Pleistocene sea level variations derived from the argentine shelf. Geochemistry, Geophysics, Geosystems 1. doi: 10.1029/2000GC000098.

Haltiner, G.J.; Martin, F.L. 1957. Dynamical and physical meteorology. McGraw-Hill: 470 p. New York.

Heaton, T.J.; Blackwell, P.G.; Buck, C.E. 2009. A Bayesian approach to the estimation of radiocarbon calibration curves: the IntCal09 methodology. Radiocarbon 51 (4): 1151-1164.

Iturraspe, R.J.; Urciuolo, A.B. 2002. Ciclos deficitarios en el régimen de sistemas lagunares de la estepa fueguina. In Congreso Nacional del Agua, No. 19, Actas: 10 p. Villa Carlos Paz, Argentina.
Jacobson, G.; Ferguson, J.; Evans,W.R. 1994. Groundwater discharge playas of the Mallee Region, Murray Basin, southeast Australia. In Paleoclimate and Basin Evolution of Playa Systems (Rosen, M.R.; editor). Geological Society of America Special Paper 289: 81-96.

Jenkinson, D.S. 1988. Soil organic matter and its dynamics. In Russell's soil conditions and plant growth (Wild, A.; editor). Eleventh edition: 564-607.

Lambeck, K. 1980. The earth's variable rotation: Geophysical causes and consequences. Cambridge: Cambridge University Press: 295 p.

Lancaster, N. 1978. Composition and formation of southern Kalahari pan margin dunes. Zeitschrift fur Geomorphologie (N.F.) 22: 148-169.

Malumián, N.; Olivero, E.B. 2006. El Grupo Cabo Domingo, Tierra del Fuego: Bioestratigrafía, paleoambientes y acontecimientos del Eoceno-Mioceno marino. Revista de la Asociación Geológica Argentina 61 (2): 139-160.

Markgraf, V. 1980. New data on the late and postglacial vegetational history of La Misión, Tierra del Fuego, Argentina. In International Palynological Conference, No. 4, Proceedings 3: 68-74. Lucknow, India.

Massaferro, J.; Recasens, C.; Larocque-Tobler, I.; Zolitschka, B.; Maidana, N.I. 2012. Major lake level fluctuations and climate changes for the past 16,000 years as reflected by diatoms and chironomids preserved in the sediment of Laguna Potrok Aike, southern Patagonia. Quaternary Science Reviews 71:167-174.

Massone, M.; Jackson, D.; Prieto, A. 1993. Perspectiva arqueológica de los Selk'nam. Centro de Investigaciones Diego Barros Arana, Dirección de Bibliotecas, Archivos y Museos: 170 p. Santiago de Chile.

Massone, M. 2003. Fell 1 Hunters' Fire hearths in Magallanes Area by the End of the Pleistocene. In Where the South Winds Blow: Ancient Evidence for Paleo South Americans (Miotti, L.; Salemme, M.; Flegenheimer, N.; editors). Center for the Study of First Americans, Texas A\&M University press: 153-159. Texas.

Mazzoni, E.; Vázquez, M., 2009. Desertification in Patagonia. In Natural hazards and human-exacerbated disasters in Latin America (Latrubesse, E.; editor). Special Volume of Geomorphology, Developments in Earth Surface Processes 13: 351-376.

McCormac, F.G.; Hogg, A.G.; Blackwell, P.G.; Buck, C.E.; Higham, T.F.G.; Reimer, P.J. 2004. SHCAL04 southern hemisphere calibration, $0-11.0$ cal kyr BP. Radiocarbon 46 (3): 1087-1092.

Meglioli, A. 1992. Glacial geology and chronology of southernmost Patagonia and Tierra del Fuego, 
Argentina and Chile. Ph.D. Thesis (Unpublished), Lehigh University: p. 216.

Montes, A. 2015. Morfología y evolución de depósitos litorales del Holoceno en la zona del río Chico, Tierra del Fuego. Tesis de Doctorado (Inédito), Universidad Nacional de la Patagonia SJB, Facultad de Ciencias Naturales, Comodoro Rivadavia: p. 308.

Montes, A.; Santiago, F.; Salemme, M.; López, R.; Magnares, I. 2016. Geoarqueología en la duna de la laguna Las Vueltas, Tierra del Fuego, Argentina. In Congreso Nacional de Arqueología Argentina, No. 19, Actas: 1622-1628. San Miguel de Tucumán.

Montes, A.; Martinioni, D. 2017. Geomorfología y paleoambientes holocenos de la costa atlántica de Tierra del Fuego entre el río Grande y el estrecho de Le Maire. In Patrimonio a orillas del Mar (Oría, J.; Vazquez, M.; Elkin, R.; editores). Editorial Cultural Tierra del Fuego: 29-44. Ushuaia.

Montes, A.; Rodríguez, S.S.; Domínguez, C.E. 2017. Geomorphology context and characterization of dunefields developed by the southern westerlies at drying Colhué Huapi shallow lake, Patagonia Argentina. Aeolian Research 28: 58-70.

Montes, A.; Bujalesky, G.G.; Paredes, J.M. 2018. Geomorphology and internal architecture of Holocene sandy-gravel beach ridge plain and barrier spits at Río Chico area, Tierra del Fuego, Argentina. Journal of South American Earth Sciences 84:172-183. doi: 10.1016/j.jsames.2018.03.012.

Morello, F. 2000. 30 años después, una primera aproximación a la Colección Marazzi (Museo Regional, Punta Arenas). Desde el País de los Gigantes. In Jornadas de Arqueologías de la Patagonia, No. 4, Universidad Nacional de la Patagonia Austral, Actas 2: 481-498. Argentina.

Mörner, N. 1991. Holocene sea level changes in the Tierra del Fuego region. Boletin IG-USP, Special Publication 8 : 133-151. São Paulo, Brazil.

Negre, J.; Santiago, F.; Salemme, M. 2017. The Underlying Spatial Structure of a guanaco (Lama guanicoe) Bonebed Assemblage in the Fuegian Region, Subantarctic Insular Argentina. Journal of Archaeological Method and Theory 26(1): 3-24. doi: 10.1007/s10816-017-9357-8

Oehlerich, M.; Mayr, C.; Gussone, N.; Hahn, A.; Hölzl, S.; Lücke, A.; Ohlendorf, C.; Rummel, S.; Teichert, B.M.A.; Zolitschka, B. 2015. Lateglacial and Holocene climatic changes in south-eastern Patagonia inferred from carbonate isotope records of Laguna Potrok Aike (Argentina). Quaternary Science Reviews 114: 189-202.
Oría, J.; Salemme, M. 2016. Visibilidad y preservación en Laguna Arturo, norte de Tierra del Fuego (Argentina). Un análisis geoarqueológico. Intersecciones en Antropología. FACSO Vol. Especial 4: 89-100.

Oría, J.; Salemme, M.; Vázquez, M. 2016. Site formation processes in relation to surface bone assemblages in the Fuegian steppe (Tierra del Fuego, Argentina). Archeological and Anthropological Sciences 8: 291-304.

Oría, J.; Salemme, M.; Santiago, F.; Montes, A. 2010. Localidad Tres Marías: un caso para evaluar la pérdida de información arqueológica por erosión eólica en la estepa fueguina. Cazadores Recolectores Del Cono Sur. Revista de Arqueología 4: 159-173. Buenos Aires.

Panigatti, J.L. 2010. Argentina 200 años, 200 suelos. INTA Ediciones: 345 p. Argentina.

Perdomo, R.; Hormaechea, J.L. 1999. A preliminary analysis of the geoid in Tierra del Fuego. International Geoid Service Bulletin 9: 171-121.

Ponce, J.F.; Rabassa, J.; Coronato, A.J.; Borromei, A.M. 2011. Paleogeographic evolution of the Atlantic coast of Pampa and Patagonia since the Last Glacial Maximum to the Middle Holocene. Biological Journal of the Linnean Society 103: 363-379.

Prohaska, F. 1976. The climate of Argentina, Paraguay and Uruguay. In Climates of Central and South America (Schwerdtfeger, W.; editor). Elsevier: 13-112. New York.

Rabassa, J. 2008. Late Cenozoic Glaciations in Patagonia and Tierra del Fuego. In The Late Cenozoic of Patagonia and Tierra del Fuego (Rabassa, J.; editor). Elsevier, Developments in Quaternary Sciences 11: 151-204. Amsterdam.

Rabassa, J.; Clapperton, C.H. 1990. Quaternary Glaciations of the Southern Andes. Quaternay Science Reviews 9: 153-174.

Rosen, M.R. 1994. The importance of groundwater in playas: a review of playa classifications and the sedimentology and hydrology of playas. In Paleoclimate and Basin Evolution of Playa Systems (Rosen, M.R.; editor). Geological Society of America Special Paper 289: 1-18. Massachusetts.

Roy, P.S. 1984. New South Wales estuaries: their origin and evolution. In Coastal geomorphology in Australia (Thom, B.G.; editor). Academic Press: 99-212.

Salemme, M.; Bujalesky, G.G. 2000. Condiciones para el asentamiento humano litoral entre Cabo San Sebastián y Cabo Peñas (Tierra del Fuego), durante el Holoceno medio. Desde el país de los gigantes. Perspectivas arqueológicas en Patagonia. Universidad Nacional de la Patagonia Austral, Río Gallegos 2: 519-531. 
Salemme, M.; Bujalesky, G.; Santiago, F. 2007. La Arcillosa 2: La ocupación humana durante el Holoceno medio en el Río Chico, Tierra del Fuego, Argentina. In Arqueología de Fuego-Patagonia. Levantando piedras, desenterrando huesos... y develando arcanos (Morello, F.; Martinic, M.; Prieto, A.; Bahamonde, G.; editores). Ediciones CEQUA: 723-736. Punta Arenas.

Santiago, F. 2013. La ocupación humana en el norte de Tierra del Fuego durante el Holoceno medio y tardío. Su vinculación con el paisaje. $1^{\text {a }}$ edición Ushuaia: Aguafuerte; Editorial Cultural Tierra del Fuego: p. 460.

Santiago, F.; Salemme, M. 2009. Las Vueltas 1: un sitio de matanza de guanacos del Holoceno Tardío en el norte de Tierra del Fuego (Argentina). In Arqueología de Patagonia. Una mirada desde el último confín (Salemme, M.; Santiago, F.; Alvarez, M.; Piana, E.L.; Vázquez, M.; Mansur, M.E.; editores). Editorial Utopías: 785-804. Ushuaia.

Santiago, F.; Salemme, M. 2010. A guanaco kill site in Tierra del Fuego, Argentina. Before Farming 2/2010: 1-17.

Santiago, F.; Salemme, M. 2016. Guanaco hunting strategies in the northern plains of Tierra del Fuego, Argentina. Journal of Anthropological Archaeology 43: $110-127$.

Santiago, F.; Salemme, M.; Pardiñas, U. 2016. Análisis de restos de roedores del sitio arqueológico Las Vueltas 1, Tierra del Fuego, Argentina. Universidad de Buenos Aires, Facultad de Filosofía y Letras. Arqueología 22: 211-230.

Schäbitz, F.; Wille, M.; Francois, J.P.; Haberzettl, T.; Quintana, F.; Mayr, C.; Lücke, A.; Ohlendorf, C.; Mancini, V.; Paez, M.M.; Prieto, A.R.; Zolitschka, B. 2013. Reconstruction of palaeoprecipitation based on pollen transfer functions e the record of the last $16 \mathrm{ka}$ from Laguna Potrok Aike, southern Patagonia. Quaternary Science Reviews 71: 175-190.

Schellmann, G.; Radtke, U. 2010. Timing and magnitude of Holocene sea-level changes along the middle and south Patagonian Atlantic coast derived from beach ridge systems, littoral terraces and valley-mouth terraces. Earth Science Reviews 102: 1-30.

Schnack, E.J.; Isla, F.I.; De Francesco, F.D.; Fucks, E.E. 2005. Estratigrafía del Cuaternario marino tardío en la Provincia de Buenos Aires. In Geología y Recursos Minerales de la Provincia de Buenos Aires (De Barrio, R. E.; Etcheverry, R. O.; Caballé, M. F.; Llambías, E.; editores). In Congreso Geológico Argentino, No. 16, Relatorio: 159-182. La Plata, Argentina.
Servicio de Hidrografía Naval. 2008. Tablas de marea para el año 2008. Puertos de la República Argentina y Puertos Principales de Brasil, Uruguay y Chile. Publicación H 610. Armada Argentina: 494 p.

Servicio Meteorológico Nacional. 1986. Estadísticas meteorológicas (1971-1980). Estadística $\mathrm{N}^{\circ} 36$. Fuerza Aérea Argentina: p. 388.

Shaw, P.A.; Bryant, R.G. 2011. Pans, playas and salt lakes. In Arid zone geomorphology: process form and change drylands, third edition (Thomas, D.S.G.; editor). Wiley, Chichester: 373-401.

Sloss, C.R.; Murray-Wallace, C.V.; Jones, B.G. 2007. Holocene sea-level change on the southeast coast of Australia: a review. The Holocene 17 (7): 999-1014.

Stuiver, M.; Reimer, P.J. 1993. Extended ${ }^{14} \mathrm{C}$ data base and revised CALIB $3.0{ }^{14} \mathrm{C}$ age calibration program. In Calibration 1993 (Stuiver, M.; Long, A.; Kra, R.S.; editors). Radiocarbon 35(1): 215-230.

Tricart, J. 1969. Le modelé des régions Séches. SEDES: p. 322. París.

Tukhanen, S. 1992. The climate of Tierra del Fuego from a vegetation geographical point of view and its ecoclimatic counterparts elsewhere. Acta Botanica Fennica 145: 1-64.

Villarreal, M.L.; Coronato, A.J. 2017. Characteristics and nature of pans in the semiarid temperate-cold steppe of Tierra del Fuego. In Advances in Geomorphology and Quaternary studies in Argentina (Rabassa, J.; editor). Springer Book Series: 203-224.

Violante, R.A.; Parker, G. 2004. The post-Last Glacial Maximum transgression in the de la Plata river and adjacent Inner Continental Shelf, Argentina. Quaternary International 114: 167-181.

Violante, R.A.; Costa, I.P.; Cavallotto, J.L.; Paterlini, C.M.; Marcolini, S.; Bozzano, G. 2014a. Rasgos morfosedimentarios, procesos y evolución de la plataforma continental Argentina desde el Último Máximo Glacial. Revista de la Asociación Geológica Argentina 71 (2): 292-310.

Violante R.A.; Paterlini, C.M.; Marcolini, S.I.; Costa, I.P.; Cavallotto, J.L.; Laprida, C.; Dragani, W.; García Chapori, N.; Watanabe, S.; Totah, V.; Rovere E.I.; Osterrieth, M.L. 2014b. The Argentine continental shelf: morphology, sediments, processes and evolution since the Last Glacial Maximum. In Continental Shelves of the World: Their Evolution During the Last Glacio-Eustatic Cycle (Chiocci, F.L.; Chivas, A. R.; editors). Geological Society of London, Memoirs 41: 55-68. London. doi:10.1144/M41.6.

Manuscript received: August 6, 2018; revised/accepted: February 25, 2019; available online: September 30, 2019. 